\title{
TROPES AND PICTORIAL METAPHORS: FIGURES OF SPEECH AND VISUAL METAPHOR ANALYSIS IN NATURE TOURISM OBJECT PROMOTION OF WEST JAVA-INDONESIA
}

\author{
Kasno Pamungkas ${ }^{1}$, Eva Tuckytasari Sujatna ${ }^{2}$ Heriyanto $^{3}$ \\ ${ }^{1}$ Mr., Department of Linguistics Faculty of Humanities, Universitas Padjadjaran, INDONESIA \\ kasno.pamungkas@unpad.ac.id \\ ${ }^{2}$ Dr., Department of Linguistics Faculty of Humanities, Universitas Padjadjaran, INDONESIA \\ eva.tuckyta@unpad.ac.id \\ ${ }^{3}$ Dr., Department of Linguistics Faculty of Humanities, Universitas Padjadjaran, INDONESIA \\ heriyanto@unpad.ac.id
}

\begin{abstract}
This research is entitled "Tropes and Pictorial Metaphors: Figures of Speech and Visuals Analysis in Nature Tourism Object Promotion of West Java Indonesia". This paper tries to describe the Tropes and pictorial metaphors in nature tourism object promotion. The purpose of this study is to describe the metaphors predominantly found in the texts of the promotion of nature tourism in West Java and their interaction with the visuals of the tourism destination accompanying the promotion text. The frameworks of this research are Tropes as a rethorical strategy to strengthen their speeches and composition by Danesi (2004) and Pictorial Metaphors by Forceville (2015).

The data used in this research are taken by observing and documenting the tourism information in West Java Province and its website, interviewing the person in charge of tourism office in West Java province government and doing literature review of metaphors and tourism language. The results of this research show that tropes employed in the promotion texts are Metonymy, Personification, Simile and Hyperbole. Tropes tries to create an imagery of the tourism destination using words or phrases containing metaphors. In addition, the pictorial metaphors found in promoting the tourism objects are Conceptual Metaphor and Simile, it is necessary to promote the tourism object by using visuals to make the promotion more alive.
\end{abstract}

Keywords: Tropes, Pictorial Metaphors, Nature Tourism, Promotion

\section{INTRODUCTION}

Trope has become an important aspect of language since a long time ago. Forceville (2015) stated that 
Aristotle helped establish its fame and appeal by claiming that metaphor is essential both for rhetoric and for poetry. A good using of metaphor is a mark of someone's genius. Lakoff and Johnson through their monograph Metaphors We Live By define metaphor as "understanding and experiencing one kind of thing in terms of another" (Lakoff/Johnson 1980, 5), they claimed that human beings think metaphorically, and systematically metaphorize abstract, complex phenomena in terms of concrete, embodied phenomena.

In the past decades, there have been a lot of researches and studies on Metaphor. Lakoff and Johnson (1980) fathered Conceptual Metaphor Theory (CMT), which had a major impact on Cognitive Linguisticsoriented scholarship. Metaphorical thinking also displays significant cultural differences (e.g., Gibbs/Steen 1999; Yu 1998; Kövecses 2005). Forceville (2015) stated that CMT has in the past 35 years spawned many dozens of books, PhD projects and conferences, probably thousands of papers and two journals: Metaphor and Symbol and Metaphor and the Social World. For an idea of its current state, Gibbs (2008) and Kövecses (2010) are the best overviews. Nevertheles, the research on tropes in tourism promotion is still limited. Sujatna ET, Heriyanto, and Kasno Pamungkas (2015) discuss the Metaphors in Jawa Barat Tourism Destination Promotion Text then find the existence of dead metaphor, cliche metaphor, and standard metaphor in the promotion texts. Meanwhile, Kasno Pamungkas \& Eva Tuckytasari (2016) discuss Figurative Meaning in Nature Tourism Object Promotion Texts: A Study in Garut Regency West Java. It focuses on the findings of Simile, Personification, and Metaphor in the promotion texts. This research, however, tries to discuss the tropes and pictorial metaphor in the promotion text in order to see existence of tropes and pictorial metaphor particularly to determine the best strategy of using metaphors in promoting the tourism.

Tourism is always tied with language and culture since a lot of tourism activities are, directly or indirectly, supported with both language and culture (Dann, 1996, Ignjic, 2001 and Hou, 2005). We can see, relics of ancient times, including ancient scripts, written in the language and runes as well, filling and also adorn museums in many countries, including America and Europe, and is regarded as masterpieces which are priceless is a reflection of past cultures (During, 1999).

In the promotion of tourism, it can be found peculiarities of color, not only the figures of speech such as metaphors and similes, but also the choice of words combined with beautiful and interesting pictures with the aim of provoking the imagination of the reader to visit the destinations promoted (Dann, 1996). For example, the expression in the form of metaphors such as 'emeralds on the equator' or 'Pearl of Asia' is often used to describe a beautiful place or islands as beautiful as pearls or emeralds so that people imagine about a beautiful place because of 'emerald' and 'pearl', while the 'equatorial' and 'Asia' is a description of the place. However, there are also the attractiveness of 'Asia' itself, i.e. diverse uniqueness which are not found in Western countries, and this will be the new experience different from the daily life of the West. This is important because the one which is normally expected by a tourist is a new experience different from those encountered in daily routine life.

Therefore, tourism promotion text should be presented in a good and interesting language that is not only able to provide a clear description, but also to persuade tourists to visit the attractions being promoted. Due to the breadth of the tourism problem, this research will be limited to the study of tourism language, especially the figurative meanings in the promotion of tourism in Garut. Located in the southern region of West Java - Indonesia, Garut Regency is selected as the object of research since the nature tourism potency includes coastal tourism, eco tourism, mountain tourism and others.

\subsection{West Java Province - Indonesia and Its Tourism Map}

Located in western of Java Island, West Java Province stretches from Sunda Strait in the west to the borders of Central Java in the east. West Java Province is situated between 5 50'-7 50' South parallels and 104 48'10448 East meridians. West Java Province is bordered of:

- Northern: Java Sea and Jakarta

- Western: Banten Province and Hindia Ocean

- Southern: Hindia Ocean

- Eastern: Central Java Province.

This strategic geographical condition becomes an advantage for West Java especially for communication and transportation aspects. Geographically, the condition in northern area is plain, while southern one is a hilly area with beaches, and the middle region is mountainous. This province has its own unique culture and language, called Sundanese which is also used to call its people. The ancient kingdoms of Tarumanegara, Pajajaran, Banten and Cirebon have strong influence to this province. Nowadays, West Java consists of 18 
regencies, nine mayoralties, 584 districts, 5,201 villages and 609 sub districts. The capital city of West Java province is Bandung city which is situated $180 \mathrm{~km}$ southeastern of Jakarta.

Topographically, West Java has a characteristic as part of a volcanic belt, spanning from Sumatra Island to the northern part of Sulawesi Island. Its land can be divided into a region with steep mountains with altitude of more than 1,500 meter above the sea level in the South, moderate hill with elevation of 100 to 1,500 meters, and plain region in the north with elevation between 0 and 10 meters and river region.

Since its unique geographical, topographical, and climatological conditions, West Java has a large number of interesting nature tourism objects. They are spreaded in almost all regions and cities in West Java. The mountainuous areas have various nature tourism objects on craters, hot water spring, forest and conservation, waterfall, etc. On the other hand, West Java is rich of nature tourism objects on beaches, caves, in southern and northern areas.

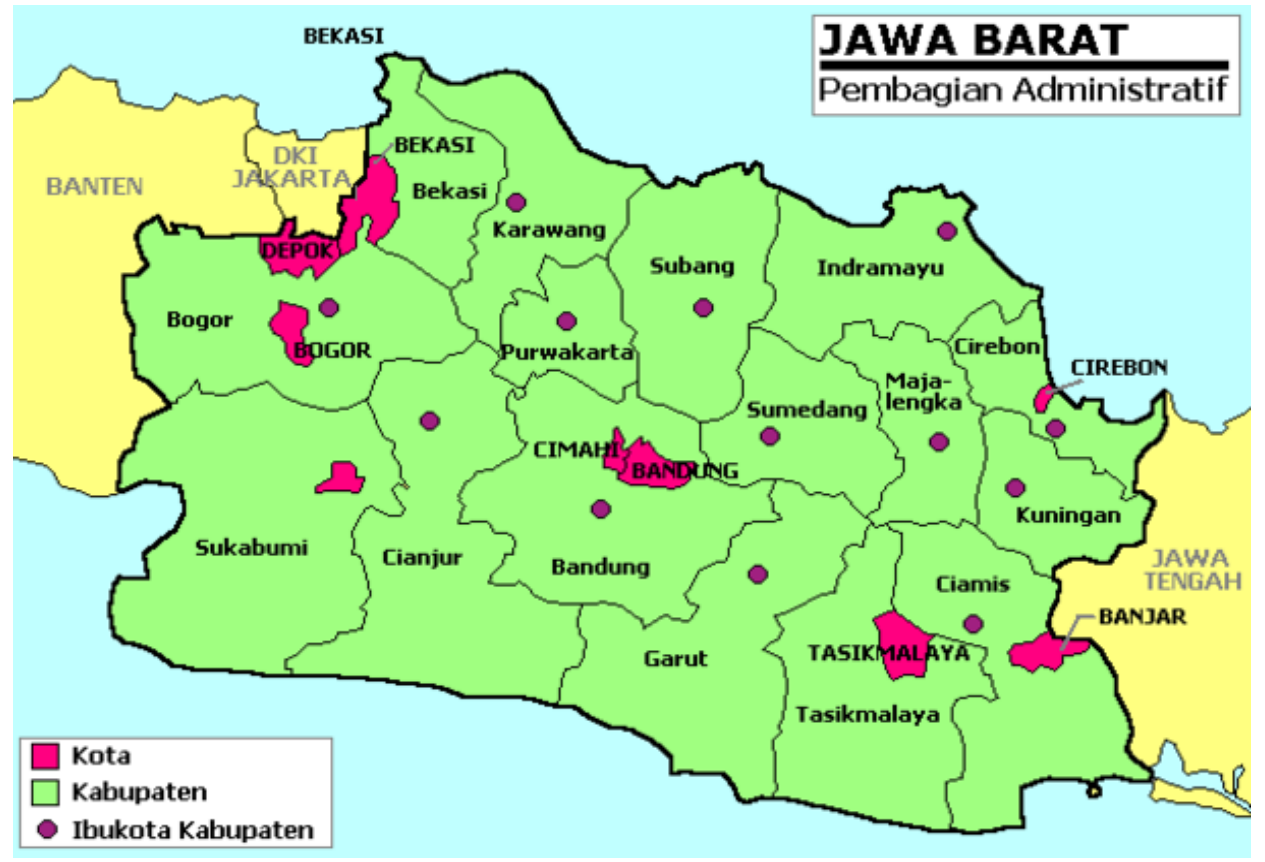

(source: West Java Tourism and Culture Office)

Fig. 1: Tourism Map of West Java Province, Indonesia

Based on data of Tourism and Culture Office of West Java Province, there are 28 regions and cities which are included in West Java Tourism Map. Regarding the nature tourism objects, there are 19 mountain tourism, 33 beach tourism, 12 agro and park tourism, 36 waterfall and river tourism, 35 lake tourism, and 10 cave tourism. These nature tourism objects are spreaded in 28 regions and cities.

\section{RESEARCH METHOD}

This research uses qualitative descriptive method. Qualitative research assumes that all knowledge is relative, that there is a subjective element to all knowledge and research and that holistic ungeneralisable studies are justifiable (Nunan, 1992: 3). The aim of descriptive research is to describe condition and phenomenon status. In that case, it intends to describe the tropes and its intentions contained in the promotion of nature tourism in West Java. In addition to the descriptive, this research discusses and analyzes the types and meaning of the tropes and their relation with the visuals of the promotion. The authors obtained data from some electronic and printed media such as brochure, booklet, etc. from the Tourism Office of West Java Province Government and their website. After collecting the data, the writer classified the data related to the trope types. The data are analyzed in order to see the tropes based on their classification, and then the analysis is associated with the visuals of the tourism object in order to see the correlation between the tropes in the promotion texts and the visuals of the tourism object.

\section{THEORETICAL FRAMEWORK}

\subsection{Tropes}

Tropes or metaphor has been used as a rhetorical strategy to strengthen their speeches and composition. 
Trope is defined as the use of a word or phrase denoting one kind of idea in place of another word or phrase for the purpose of suggesting a likeness between the two (Danesi, 2004, p. 116). He divides the tropes into the following domain of rhetorical speech:

1. Climax: arrangement of words, clauses, or sentences in the order of their importance, the least forcible coming first and the others rising in potency until the last: "It is an outrage to scoff at her; it is a crime to ridicule her; but to deny her freedom of speech, what shall I say of this?"

2. Anticlimax: the opposite trope, namely the sequencing of ideas that abruptly diminish in importance at the end of a sentence or passage, generally for satirical effect:"I will shoot him down first, and then I will talk to him."

3. Antithesis: refers to juxtaposition of two words, phrases, clauses, or sentences contrasted or opposed in meaning in such a way to give emphasis to contrasting ideas: "To err is human, to forgive divine."

4. Apostrophe: technique by which an actor turns from the audience, or a writer from his or her readers, to address a person who usually is either absent or decreased, or to address an inanimate object or an abstract idea: "Hail, Freedom, whose visage is never far from insight."

5. Euphemism: the substitution of a delicate for inoffensive terms or phrase for one that has coarse, sordid, or other unpleasant associations, as in the use lavatory or restroom for toilet.

6. Exclamation: sudden outcry expressing strong emotion, such as fright, grief, or hatred.

7. Hyperbole: the use of exagerration for effect: "My friends drink ocean of water"

8. Litotes:technique of understatement so as to enhance the effect of the ideas expressed:"Franz Boas showed no inconsiderable analytical powers as an anthropologist".

9. Simile: technique of specific comparison by means of the words like or as between two kinds of ideas or objects:"You are as light as a feather".

10. Metonymy:the use of word or phrase for another to which it bears an important relation, as the effect for the cause, the abstractfor the concrete, etc.: "She is the head of our family."

11. Conceit: extravagant metaphor or simile, for making an analogy between totally dissimilar things:" Love is a worm"

12. Irony: lightly sarcastic mode of speech, in which words are used to convey a meaning contrary to their literal sense:" I really love the pain you give me"

13. Onomatopoeia: the immitation of natural sounds by words: the humming bee, etc.

14. Oxymoron: combination of two seemingly contradictory or incongruous words: "My life is a living death"

15. Paradox: a statement that appears contradictory or inconsistent: "She is well-known secret agent"

16. Personification: representation of inanimate objects or abstract ideas as living beings:"Necessity is the mother of invention"

17. Rhetorical Question: questioning strategy intended not to gain information but to assert more emphatically the obvious answer to what is asked: You do understand what I mean, don't you?"

18. Synecdoche: the part is made to stand for the whole, the whole for a part,the species for the genus, example: "The president's administration contained the best brains in the country."

\subsection{Pictorial Metaphor}

Forceville (1996) identifies four subtypes of pictorial/visual metaphor as explained below.

\subsubsection{Contextual Metaphor}

This type of pictorial metaphor visually renders the object and turns into the target of a metaphor by being depicted in a visual context in such a way that the object is presented as if it were something else - the source (Forceville, 2015). In order to clarify this contextual metaphor, below is given an example of this type of metaphor. 


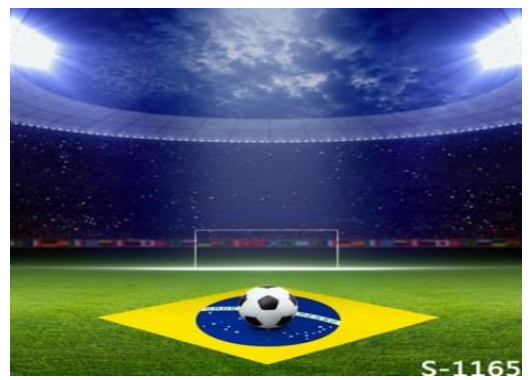

(source: http://www.google.com/iklan.produk.bola)

\section{Fig. 2: Contextual Metaphor in Pictorial Metaphor}

It can be seen here a ball product mounted on a pedestal in such a way that we are invited to construe the metaphor " the ball is Brazilian". The cues are the visual context of the pedestal and the spatial context of a football stadium in Brazil which is clarified by the flag of Brazil. The picture clearly demonstrates the need for background knowledge. It helps the construal of the metaphor at least for the designated audience. But the point to be emphasized here is the categorization of the subtype: it is the visual context that provides the source. If one removes the ball from the pedestal and puts it on the place of a different type of stadium and unclear country, the metaphor is no longer there. The ball product has the prestige and aesthetics attached to glorious stadium in Brazil.

\subsubsection{Hybrid Metaphor}

The typical of this metaphor is that the target and the source have been physically integrated. We can recognize both, but we cannot "disentangle" them; they form a single gestalt (Forceville, 2015). To make the definition clearer, an example of this type is in the figure below.

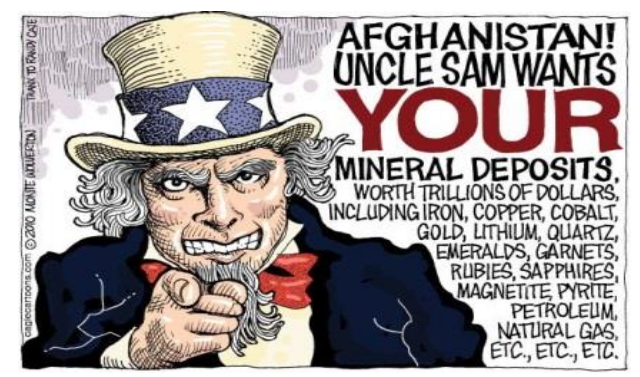

(Source:http://www.google.com/iklanBush)

\section{Fig. 3: Hybrid Metaphor in Pictorial Metaphor}

It is a cartoon of George Bush depicted as Uncle Sam, representing America. He is represented as the person who does terror in Afghanistan but has other intensions of his teror i.e. to rob the wealth and property of Afghanistan.

\subsubsection{Simile}

Simile compares the target to a source resembling one way or another. This can be done visually by juxtaposing target and source, by presenting them in the same form or posture or depicting them with the same attention-drawing colour or in the same (deviant) style, by lighting them identically or by any combination of these (Forceville, 2015). Look at the figure 4 to clarify its definition.

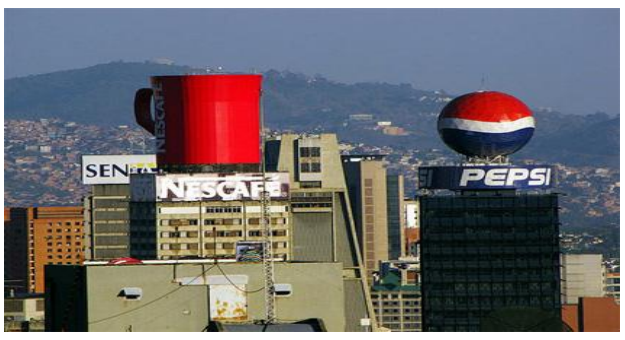

(Source: http://www.google.com/iklan pepsi cola)

Fig. 4: Simile in Pictorial Metaphor 
The Nescafe cup is juxtaposed to higher than the skycrapper building of the city. It intens to declare that drinking Nescafe has a high class as which higher than the buildings.

\subsubsection{Verbo-pictorial Metaphor}

According to Forceville (2015), "it was misleading to categorize this as a subtype of pictorial/visual metaphor, since, in fact, the examples discussed under this subtype are unambiguous multimodal specimens of the verbo-pictorial variety". The examples proposed, 2 pictures combining chess and boxing, in the absence of any contextual cues, it is construed that the visual element as the target, and the verbal element as the source, rather than vice versa. His interpretation of the first picture would be something like "Good boxing requires all the planning and intellectual creativity of good chess playing," and for second picture, "Good chess playing requires the forcefulness and brutality of good boxing." Incidentally, the reason we are likely to construe a metaphor here is that this is the only way in which this word \& image combination achieves relevance.

\subsubsection{Integrated Metaphors/Product Metaphors}

According to Forceville (2015), this type of metaphor is the work by Thomas van Rompay and Nazlı Cila, which only works for three-dimensional objects. (Van Rompay in Forceville, 2015) researched how threedimensional products (and by extension, I propose, buildings) lend themselves to metaphorizing by creating a product (the target) that assumes crucial formal qualities of something else (the source), with the goal of bestowing formal and/or conceptual features associated with that source onto that product.

\subsection{Language of Promotion Texts}

According to Danesi (2004: 268-269), there are some techniques that advertisers use to realize the language of promotion such as slogans, i.e:

- Jingles, enhancing memory of the products: Have a great day, at McDonald's.

- Use Imperative form, the effect of advice coming from an unseen authoritative source: Drink milk, love life; Trust your senses.

- Formulas, meaningless statements sound truthful: A Volkswagen is a Volkswagen.

- Alliteration, repeating sounds in a slogan or jingle increases the likelihood that a brand name will be remembered and be imbued with a poetic quality: The Superfree sensation (alliteration of $s$ ).

- Absence of language, strategically avoiding the use of any language whatsoever, suggesting, by implication that the product speaks for itself.

- Intentional omission, e.g. like Don't tell your friends about ...;

- Metaphor, powerful imagery for the product: Come to where the flavor is ... Marlboro country.

- Metonymy, also creating powerful imagery for the product: Bring a touch of Paris into your life.

From those characteristics, it can be found an agreement that metaphor or trope is one of the strategic linguistic aspect to promote the products particularly nature tourism.

\section{RESULTS}

As a rich city in nature tourism attractions, West Java Province has a wide variety of interesting objects to visit. This was confirmed by the appeal of the campaign carried out by either the Department of Tourism Republic of Indonesia and the Tourism Office in West Java. Promotion is done through the media image that comes with informative text. In the campaign, the text is not only using sentences, clauses and phrases effectively but it is also peppered with some kind of tropes that appear in the text of the tourism promotion in West Java province dominated by the particular tropes. Since there are a large number of tourism objects, the discussion of tropes in the tourism promotion is classified according to the type of nature tourism object:

\subsection{Santolo Beach}

"Sampai-sampai sebagian kalangan menyebut Pantai Santolo bak surga tersembunyi di selatan Garut. Lautnya terbentang luas membentuk garis horizon di kaki langit biru dengan deburan ombaknya yang khas. Hamparan atol seluas 35 hektare juga menyuguhkan pemandangan menakjubkan. Gugusan karang hitam berbagai bentuk dipadu pasir coklat muda." 


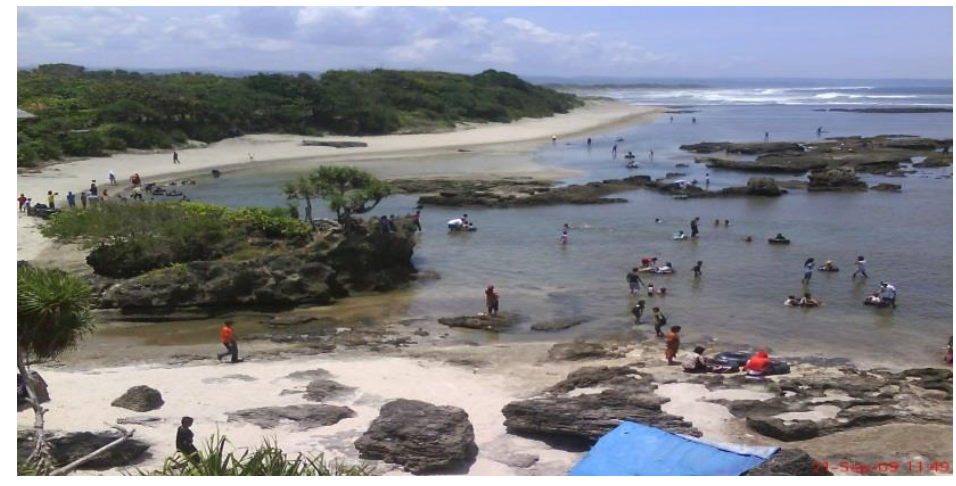

(Source: http://www.disparbud.jabarprov.go.id)

Located in Garut Regency, Santolo Beach has exotic and unique view. In the promotion text above, it is used some kinds of trope i.e. Simile which can be found in the statement 'bak surga tersembunyi'. The statement describes the beauty of the beach Santolo which means the Santolo Beach is like hidden heaven in the southern Garut. The other trope is Metonymy in the phrase 'kaki langit biru' which uses human body parts, to bear an important relation, on the expression of other scientific language to clarify the meeting point between the sea surface to the boundary line of the sky which indicates that the ocean view is very spacious along the eye can see. Furthermore, the beauty of the Santolo beach is described with the use of Hyperbole in phrase 'Hamparan atol' in the utterances ' Hamparan atol seluas 35 hektare juga menyuguhkan pemandangan menakjubkan", and phrase 'gugusan karang hitam' in the utterance ' Gugusan karang hitam berbagai bentuk dipadu pasir coklat muda'. The use of Hyperbole in both expression attempts to describe, in the exagerration effects, the physical description and situation of Santolo beach. Furthermore, the Hyperbole has a certain emotional warmth to make the tourists interested to visit Santolo beach. Then, it is enforced with the using of Personification in the statement 'menyuguhkan pemandangan menakjubkan' which means the beach is able to act as living being to present the wonderful view.

Regarding the pictorial metaphor, the promotion contain Simile since the picture looks like a heaven that can be seen from its natural, comfortable, and wonderful situation. The blue sky represents the high, clear and sunny day. It is perfected with the green plants, black coral, clean and fresh water in which those all are able to give a peace of life like in a heaven. The pictorial metaphor is in line with the Simile trope above which describe this tourism object is like hidden heaven.

\subsection{White Crater}

"Di ketinggian Gunung Patuha, tersembunyi keindahan bekas kawah tua yang unik. Bau belerang akan menyambut Anda begitu tiba di tebing kawah, menjadi sajian yang tidak terpisahan ketika mengagumi kawah berwarna hijau muda yang dikelilingi oleh pasir putih serta riak air dalam kawah yang bertabur asap tipis serta sesekali letupan lumpur hidup, menjadikannya sebuah atraksi alam yang tiada duanya. Secara geologis, Kawah Putih terbentuk dari aktifitas letusan Gunung Patuha yang terjadi di abad ke-XII. Nama Patuha sendiri berasal dari nama awal gunung ini, Gunung Sepuh

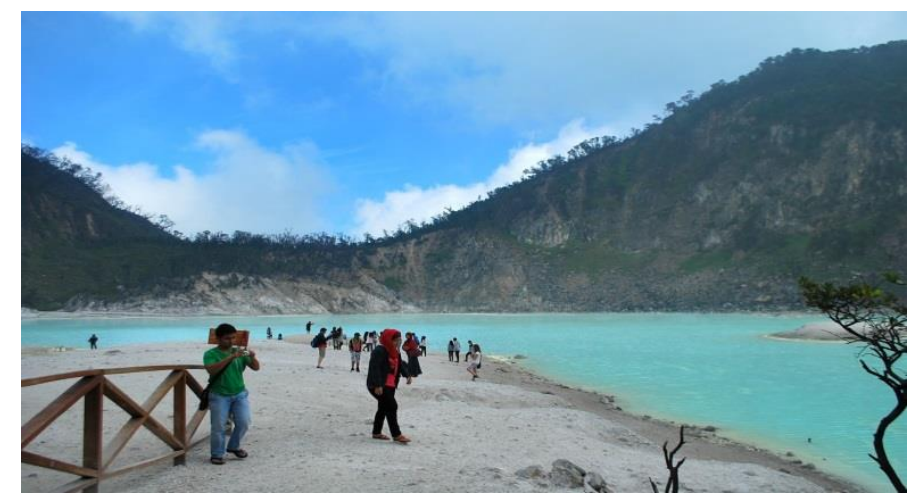

(Bahasa Sunda untuk 'tua'). “

(Source: http://www.disparbud.jabarprov.go.id)

The promotion text of this White Crater tourism object contains some tropes i.e. Personification in the word 'menyambut' at the statement 'Bau belerang akan menyambut Anda begitu tiba di tebing kawah', which 
means the tourism object as an inanimate thing is like living beings that is able to do an action 'to greet' like human. The following trope is Metonymy in the word 'sajian' at the statement 'menjadi sajian yang tidak terpisahan ketika mengagumi kawah berwarna hijau muda yang dikelilingi oleh pasir putih..." which uses the word for appointing the sulphur aroma is the part of this important aspect of the tourism. In addition, it has another personification i.e. the word 'lumpur hidup' in "...riak air dalam kawah yang bertabur asap tipis serta sesekali letupan lumpur hidup, menjadikannya sebuah atraksi alam yang tiada duanya..." that represents as if the mud in the crater is living as human. It is used to describe the little explosion of the mud in the surface of crater at all times.

In the aspect of pictorial metaphor, it can be seen the presence of the visuals in which the white color dominating the view. It clarifies that the contextual metaphor of the visual influence the naming of the tourism object since the white sands and white mud dominate the situation of the crater.

\subsection{Cipanundaan Waterfall}

"Curug Cipanundaan berada di kaki Gunung Sanggabuana dengan 3 (tiga) buah Curug jadi satu dalam satu areal seperti tangga, curungan air ditunda dalam kolam kesatu, turun lagi di kolam kedua, turun lagi ditunda dalam kolam ketiga, jalan ke Air Terjun Cipanundaan adalah masih perawan dengan jalan setapak berlikuliku, naik turun, melewati sungai berbatu besar, sebelah kanan tebing disebelah kiri jurang dengan sungai."

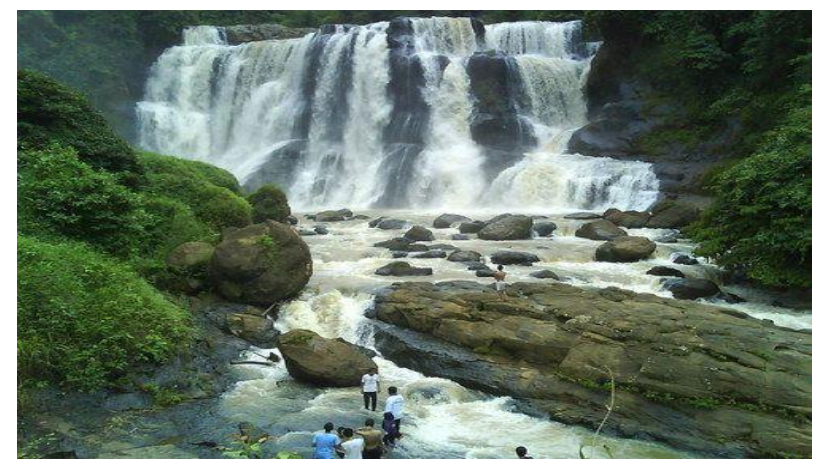

(Source: http://www.disparbud.jabarprov.go.id)

Located in Karawang Regency, Cipanundaan waterfall has exotic view since the waterfall consists of three stages. In its promotion text, it is found two tropes i.e. Metonymy in the word 'kaki gunung Sanggabuana' that uses the words to tell that the location of the waterfall is, identical to foot position, in the lower part of the mount. It bears an important relation between the waterfall and Mount Sanggabuana. For instance, the fountain of the waterfall is derived from the mount. Another trope is Simile i.e the word 'perawan' in the statement jalan ke Air Terjun Cipanundaan adalah masih perawan dengan jalan setapak. This trope compares the way to the waterfall is like a 'virgin girl' that is still original and has not been modified with concrete or asphalt.

In relation with the pictorial metaphor, this promotion of waterfall Cipanundaan has contextual metaphor. It can be identified from its visuals. It shows that the waterfall is falling down into three-stage ponds. Water from the highest peak falls onto the lower pond then falls again onto the lowest one. This visual strengthens the naming of the waterfall, 'Panundaan' which means the water delays falling onto the ground since it is hung up by the three-stage ponds.

\subsection{Mount Tangkuban Parahu}

"Duduk dengan anggunnya mendominasi panorama Bandung utara, Gunung Tangkuban Perahu adalah salah satu gunung berapi yang masih aktif di Jawa Barat. Berada di ketinggian $2084 \mathrm{~m}$ dpl, gunung berbentuk unik ini telah menarik banyak pengunjung selama puluhan tahun yang datang untuk melihat lebih dekat kawahnya, menikmati panorama lembah sekelilingnya, serta lebih akrab dengan cerita rakyatnya yang terkenal, Sangkuriang. Berdasarkan legendanya, gunung ini terbentuk akibat kemarahan Sangkuriang yang merasa gagal dalam mengabulkan permintaan pembuatan danau dan perahu besar dari Dayang Sumbi (merupakan kisah cinta terlarang antara seorang anak dengan ibu kandungnya sendiri). Dari puncak menara Gedung Sate di Kota Bandung, Anda dapat melihat dengan sangat jelas bentuk fisik Gunung Tangkuban Parahu yang benar-benar menyerupai perahu terbalik." 

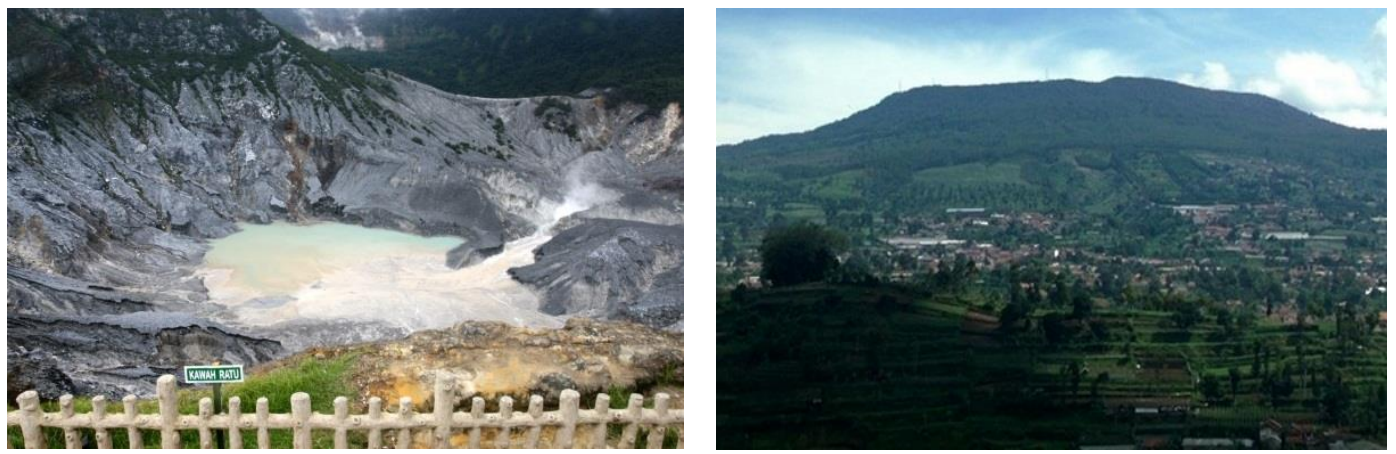

(Source: http://www.disparbud.jabarprov.go.id)

As one of the tourism belle in West Java, Mount Tangkuban Parahu is a compulsory destination to visit. It is located in Bandung Barat Regency, precisely northern of Bandung city. From its promotion, it can be identified one kind of tropes i.e. personification. The first one is the word 'duduk' in the statement "Duduk dengan anggunnya mendominasi panorama Bandung Utara, Gunung Tangkuban Parahu ...". It represents the Mount as a living being that can sit like a human. Another personification is the word 'menarik' in "menarik banyak pengunjung selama puluhan tahun". It means that the mount is like a human that it is able to attract people to visit and enjoy its view.

In term of pictorial metaphor, the visuals of the promotion shows a picture that the mount is as an overturned boat. It creates a context that visually renders the object and turns into the target of a metaphor by being depicted in a visual context in such a way that the mount is presented as if it is an overturned boat. Therefore, the naming of the mount is influenced by the visuals of the mount.

\subsection{Sela Bintana Park}

"Hamparan rumput yang luas, bergoyang tertiup angin ditambah panorama pepohonan pinus yang rapat seolah menciptakan surga di depan mata. Anda dapat menikmati keindahan alam dan hawa pengunungan yang masih sejuk di sini bersama keluarga".

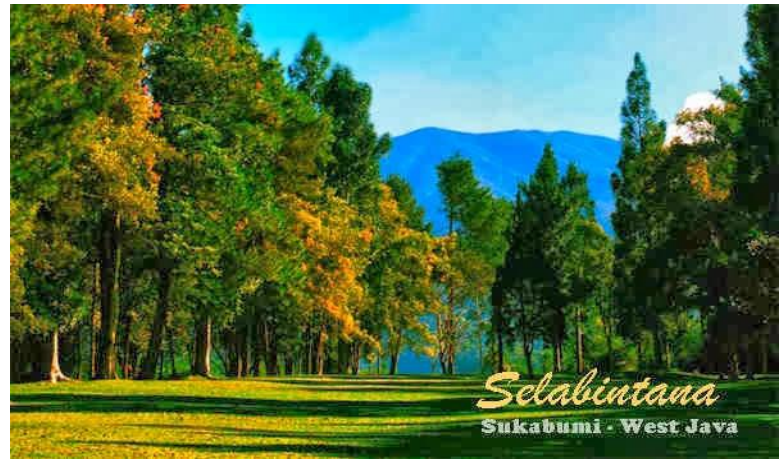

(Source: http://www.disparbud.jabarprov.go.id)

In the promotion text of Sela Bintana Park, it is found some tropes namely Hyperbole in the word 'Hamparan' contained in the statement "Hamparan rumput yang luas". It aims to raise an exaggerative effect that the grass is so wide that it creates a beautiful green view. Another trope found in the promotion text is personification i.e. the word "bergoyang in the statement "bergoyang tertiup angin" which means that, blown by the wind, the grass is able to dance like human. Another personification is the word 'menciptakan' in the statement "panorama pepohonan pinus yang rapat seolah menciptakan surga di depan mata" which means that the pine trees are, doing action like human, able to create a heavenly scenery.

Regarding the pictorial metaphor, it shows that green color dominating the visuals is the conceptual metaphor of park tourism. It creates a context that visually renders the Sela Bintana park and turns into the target of a metaphor by being depicted in a visual context in such a way that the park is presented as if it is a heaven which is so near in front of the eyes. 


\section{CONCLUSION}

The results of this research show that the tropes often employed are metonymy, personification, simile and hyperbole. Metonymy means to bear an important relation, on the expression of other scientific language to clarify the position and location of the tourism object. Meanwhile, the personification uses living creature as the imagery of tourism object that has a deeper and more alive meaning as if the tourism objects are able to act like a human. On the other hand, Simile is used to make comparison between the tourism object and other clearer things. The use of simile in the promotion text is able to provide confirmation of meaning and message as well as a clearer description of the tourism objects with the things being compared. It aims to make readers imaging the tourism object as interesting as the things being compared. The using of Hyperbole, as the last trope used in this research, has purpose to raise exaggerative effect of the tourism object features to influence the readers. The pictorial metaphors dominating the tourism promotion are Conceptual Metaphor and Simile which support the tropes employed in the texts of promotion. Both of the Tropes and Pictorial Metaphors play strategic function in tourism promotion especially to help the readers imaging the tourism objects, then it is able to change the readers become tourists since they are interested to visit the tourism objects.

\section{REFERENCE LIST}

Carnie, Andrew. (2001). Syntax. Oxford: Blackwell Publishers.

Chaika, Elaine. (1989). Language: The Social Mirror. New York: Newburry House Publisher.

Creswell, John W. (2013). Desain Penelitian: Pendekatan Kualitatif, Kuantitatif dan Campuran. Terjemahan Achmad Fawaid. Yogyakarta: Pustaka Pelajar

Eder, Katharina. (2009). Metaphor and Culture. Norderstedt : GRIN Verlag.

Edi Subroto, D. (1992). Pengantar Metode Penelitian Linguistik Struktural. Surakarta: UNS Press.

Forceville, Charles (forthc.). "Pictorial and Multimodal metaphor." In: Nina- Maria Klug and Hartmut Stöckl, eds, Handbuch Sprache im multimodalen Kontext [The Language in Multimodal Contexts Handbook]. Linguistic Knowledge series. Berlin: Mouton de Gruyter

George Lakoff and Mark Johnson. (1980). Metaphors We Live by. Chicago: The University of Chicago Press. Jack Richards, John Platt, Heidi Weber. 1989. Longman Dictionary of Applied Linguistics. London: Longman. Kovecses, Zoltan. (2007). Metaphor and Emotion. New york: Cambridge university Press.

MacCannel, Dean. (1976). A New Theory of the Leisure Class. New York: McGraw-Hill.

McQuarrie, Edward F, David Glen Mick. 1996. Figures of Rhetoric in Advertising Language. Journal of Consumer Research 424-438.

Morley, G. David. (2000). Syntax in Functional Grammar: An Introduction to Lexicogrammar in Systemic Linguistics. London: Wellington House. B.

Newmark, Peter. (1988). A Textbook of Translation. Singapore: Prentice Hall.

Nunan, D. (1992). Research Methods in Language Learning. Cambridge: CUP.

Pamungkas, Kasno. Eva Tuckytasari Sujatna, Heriyanto. (2016). Figurative Meaning in Nature Tourism Promotion Texts: A Study in Garut Regency-West Java Indonesia. INTCESS 16 Proceeding. P.204.

O'Grady, William, Michael Dobrovolky. (1996). Contemporary Linguistics: An Introduction Second Edition. New York: St. Martin's Press.

Saville, M - Troike. (1986). The Ethnography of Communication: An Introduction. Oxford: Basil Blackwell.

Sujatna, Heriyanto, Kasno Pamungkas. (2015). Metaphors in Jawa Barat Tourism Promotion. International Journal of Humanities and Social Sciences (IJHSS). p-ISSN: 1694-2620/ Vol. 5 No. 12015 